\title{
Candidate synthetic lethality partners to PARP inhibitors in the treatment of ovarian clear cell cancer (Review)
}

\author{
NAOKI KAWAHARA, KENJI OGAWA, MIKA NAGAYASU, MAI KIMURA, \\ YOSHIKAZU SASAKI and HIROSHI KOBAYASHI
}

Department of Obstetrics and Gynecology, Nara Medical University, Nara 634-8522, Japan

Received August 18, 2017; Accepted September 14, 2017

DOI: 10.3892/br.2017.990

\begin{abstract}
Inhibitors of poly(ADP-ribose) polymerase (PARP) are new types of personalized treatment of relapsed platinum-sensitive ovarian cancer harboring $B R C A 1 / 2$ mutations. Ovarian clear cell cancer (CCC), a subset of ovarian cancer, often appears as low-stage disease with a higher incidence among Japanese. Advanced CCC is highly aggressive with poor patient outcome. The aim of the present study was to determine the potential synthetic lethality gene pairs for PARP inhibitions in patients with CCC through virtual and biological screenings as well as clinical studies. We conducted a literature review for putative PARP sensitivity genes that are associated with the CCC pathophysiology. Previous studies identified a variety of putative target genes from several pathways associated with DNA damage repair, chromatin remodeling complex, PI3K-AKT-mTOR signaling, Notch signaling, cell cycle checkpoint signaling, $B R C A$-associated complex and Fanconi's anemia susceptibility genes that could be used as biomarkers or therapeutic targets for PARP inhibition. BRCA1/2, ATM, ATR, BARD1, CCNE1, CHEK1, CKS1B, DNMT1, ERBB2, FGFR2, MRE11A, MYC, NOTCH1 and $P T E N$ were considered as candidate genes for synthetic lethality gene partners for PARP interactions. When considering the biological background underlying PARP inhibition, we hypothesized that PARP inhibitors would be a novel synthetic lethal therapeutic approach for CCC tumors harboring homologous recombination deficiency and activating oncogene mutations. The results showed that the majority of CCC tumors appear to have indicators of DNA repair dysfunction similar to those in $B R C A$-mutation carriers, suggesting the possible utility of PARP inhibitors in a subset of CCC.
\end{abstract}

Correspondence to: Dr Hiroshi Kobayashi, Department of Obstetrics and Gynecology, Nara Medical University, 840 Shijo-cho, Nara 634-8522, Japan

E-mail: hirokoba@naramed-u.ac.jp

Key words: synthetic lethality, ovarian clear cell cancer, PARP inhibitors, replication stress

\section{Contents}

1. Introduction

2. Systematic review of the literature using electronic search in the PubMed/Medline databases

3. Future opportunities in the use of PARP inhibition in CCC

4. Candidate mutated genes for enhancing the therapeutic ratio achieved by PARP inhibitors in CCC (Table IA).

5. Upregulated genes enhancing synthetic lethality of PARP inhibitors in CCC (Table IB)

6. Synthetic lethal gene partners based on chemoresistance-related genes in CCC (Table IC)

7. Discussion

\section{Introduction}

Epithelial ovarian cancer is an advanced and metastatic disease at presentation and responsible for over $50 \%$ of mortalities worldwide in female genital malignancies (1). The current standard treatment strategy for ovarian cancer is cytoreductive surgery followed by platinum- and taxane-based combination chemotherapy. Approximately $75 \%$ of patients with advanced ovarian cancer ultimately suffer from tumor recurrence with $20 \%$ of these patients having resistant disease (1). High rates of recurrence and low chemosensitivity are the two main factors that account for poor prognosis of this disease. Epithelial ovarian cancer is a highly heterogeneous disease characterized by at least two different subtypes, including distinct clinicopathologic characteristics, molecular pathogenesis, responses to treatment and patient prognosis (2). Each subtype also contains a distinct gene mutation profile and exhibits varied gene expression patterns. Type 1 ovarian cancer includes endometrioid cancer and clear cell cancer (CCC) (so-called endometriosis-associated ovarian cancer). Endometrioid cancer frequently possesses mutations in phosphatase and tensin homolog (PTEN), catenin $\beta 1$ (CTNNB1), phosphatidylinositol-4,5-bisphosphate 3-kinase catalytic subunit $\alpha$ (PIK3CA) and AT-rich interaction domain 1A (ARIDIA) (3). $P I K 3 C A$ and $A R I D I A$ are also commonly mutated in CCC and this tumor frequently shows hepatocyte nuclear factor- $1 \beta$ (HNF-1 $\beta$ ) overexpression (3). Although Type 1 cancer often appears as low-stage disease, advanced CCC is a cancer that is highly aggressive with poor patient outcome. By contrast, 
Type 2 ovarian cancer includes high-grade serous ovarian cancer (HGSC), which is the most common histotype of epithelial ovarian cancer and is characterized by advanced stage at onset. HGSC possesses nearly universal mutation in and dysfunction of (tumor protein p53) TP53 as well as frequent germline and somatic BRCA1/2 (BRCA1/2, DNA repair associated) mutations, occurring in at least $30 \%$ of tumors (3).

Recentadvances for the development of efficient personalized therapy may lead to the development of successful strategies for molecular-targeted medicine (small-molecule inhibitors or antibodies), clinical applications of immunotherapy (PD-1 and -L1 antibodies) and identification of synthetic lethal partners (4). Advances in the treatment of HGSC through use of synthetic lethal approaches have also been made. Notably, inhibitors of [poly(ADP-ribose) polymerase] (PARP) are considered the most active and exciting new personalized target therapy for the treatment of ovarian cancer, especially relapsed platinumsensitive HGSC (5). However, patients without BRCA1/2 mutations may also benefit from PARP inhibitors, suggesting a sensitive non-BRCA1/2-mutation subgroup (6).

The prevalence of CCC in Japan reaches up to $15-25 \%$ compared to those of North America and Europe with a reported prevalence of $1-12 \%(7,8)$. CCC showed a different genomic expression map from HGSC, which suggested a new target therapy (5). Despite many improvements in targeted therapy for ovarian cancer, exploration of novel synthetic lethal targets is required in CCC. Investigators have performed computational virtual screenings and further experimental validations to determine whether two-compound formulations are susceptible to synthetic lethality and may therefore indicate a therapeutic opportunity.

The aim of the present study was to determine the potential synthetic lethality gene partners for PARP inhibitions in CCC patients through virtual and biological screenings.

\section{Systematic review of the literature using electronic search in the PubMed/Medline databases}

The study aimed to determine the potential synthetic lethality gene partners for PARP inhibitions in patients with CCC through virtual and biological screenings as well as clinical studies. A PubMed (http://www.ncbi.nlm.nih.gov/ pubmed) search of the relevant literature published between January 2000 and June 2017 was performed. The search strategy included the combination of key words: ovarian CCC, HGSC, synthetic lethality, PARP inhibitors, replication stress, DNA damage and repair, and genomic instability in the titles or abstracts of articles. English language publication search results from PubMed and references within the relevant articles were analyzed. To minimize selection bias, screening of the studies was independently performed by two of the co-authors (N.K. and K.O.) after agreeing on the selection criteria.

\section{Future opportunities in the use of PARP inhibition in CCC}

Cell DNA damage occurs continually through intrinsic and extrinsic mechanisms such as chemotherapy, ultraviolet radiation, smoking, reactive oxygene species and replication errors. Activation of the conserved DNA damage response (DDR) due to genomic instability requires various DNA repair genes (9). DDR deficiency results in replication stress, commonly induces replication fork slowing or stalling and also activates DNA repair checkpoint proteins [ataxia telangiectasia mutated (ATM), ATMand Rad3-related (ATR), checkpoint kinase 1 (CHEK1)], which prevent further DNA damage (10). DDR regulates cell cycle arrest, which enables DNA repair to occur. PARP1 plays a key role in numerous cell processes including DNA repair, replication and cell death/survival balance (11). PARP1 is mainly involved in the repair of DNA single-strand breaks. Accumulation of DNA double-strand breaks (DSBs) is generally repaired by the two DNA DSB repair pathways: Homologous recombination (HR) and non-homologous end joining (NHEJ). DNA repair defects are frequently encountered in human cancers, whereas DNA repair pathways mediated by PARP1 serve as backups (11). Approximately $50 \%$ of HGSC incur germline or somatic mutations in genes related to HR [BRCA1/2, BRCA paralogs, RAD51 (RAD51 recombinase), checkpoint activation genes and Fanconi's anemia genes] and the rest incur genetic alterations in mismatch repair (MMR) genes and other genes in the HR/DNA repair pathway at high frequencies (10). The global genomewide mutational landscape revealed that the majority of HGSC patients harbor the actionable impact of germline and somatic mutations and DNA repair gene defects. HGSC cells harboring HR deficiencies are exceptionally sensitive to PARP inhibition. PARP inhibitors are an effective treatment strategy when they are used in BRCA1/2-mutated ovarian cancers, which has led to a shift in the treatment paradigm of this disease $(12,13)$. The concept of synthetic lethality interactions can be exploited in tumors that harbor germline and somatic mutations causing defective DDR/DNA repair (14). Thus, not only BRCA1/2 mutations, but also other HR deficiencies, have been established as a targeted therapy (14).

Based on a literature search, we initially identified differentially expressed genes and genomic mutations throughout the ovarian cancer between CCC and HGSC, which were recapitulated in CCC cell lines in vitro, in xenografts in vivo and in a comprehensive analysis of clinical data (15-21). We then explored virtual and biological screenings against synthetic lethal gene partners of PARP inhibition in ovarian cancer. The majority of samples were derived from patients with HGSC. Of the candidate genes that were likely to be synthetic lethal with PARP inhibitors, we selected genes that were frequently mutated, amplified, or upregulated in CCC.

This review focused on the future opportunities of the use of PARP inhibition in anticancer therapeutics for CCC. Identifying genetic biomarkers of the effects of synthetic lethal drug sensitivity also provides an approach to the development of targeted therapies for CCC.

\section{Candidate mutated genes for enhancing the therapeutic ratio achieved by PARP inhibitors in CCC (Table IA)}

PARP inhibitors are mandatory to improve the success of ovarian cancer therapy in the clinical setting (15). Loss-offunction mutations or reduced levels of genes involved in homologous repair sensitize cancer cells to treatment with PARP inhibitors. PARP1 silencing and inhibition were found to be synthetic lethal in ovarian cancers deficient in specific genes involved in the DDR such as BRCA1/2 and P53 with 
impaired HR. Approximately $50 \%$ of epithelial ovarian cancers had germline (20-50\%) and/or somatic (10\%) loss-of-function mutations in HR genes $(16,17)$. Mutated HR genes belong to DDR, BRCA1-associated, Fanconi's anemia-related and $R A D 51$-related genes. Notably, HR mutation frequency was almost similar in serous and non-serous ovarian cancers (16). It is currently unclear, however, whether PARP1 inhibitors are capable of killing CCC cells using a synthetic lethal treatment strategy. Since CCC tumors have a variety of DDR gene mutations and activation of oncogenes, there is considerable interest in finding synthetic lethal partners of PARP inhibitor sensitivity. Previous studies of gene-expression profiling and proteomics, next-generation sequencing, genomic mutations, methylation status, chromosomal amplification and loss of heterozygosity $(\mathrm{LOH})$ are discussed in the context of $\mathrm{CCC}$ biology (18-21). Furthermore, investigators have developed a new method to predict the synthetic lethality interactions: Synthetic lethality gene pairs may be predicted in functional genomic screening approaches such as CRISPR and siRNA in cancer cells treated with or without PARP inhibitors $(22,23)$.

Firstly, we identified potential targetable genomic mutations in CCC using an extensive literature search $(24,25)$. Patients with CCC (64\%) had $\geq 1$ somatic mutation (24). These included ARIDIA; PIK3CA; PTEN; KRAS proto-oncogene, GTPase (KRAS); NRAS proto-oncogene, GTPase; B-Raf proto-oncogene, serine/threonine kinase ( $B R A F)$; zincfinger protein 217; AKT serine/threonine kinase $(A K T)$; TP53; Wnt/ $\beta$-catenin (CTNNB1); microsatellite instability; mutL homolog 1; SRC proto-oncogene, non-receptor tyrosine kinase; ETS proto-oncogene 1, transcription factor; protein kinase DNA-activated, catalytic polypeptide; APC membrane recruitment protein 1; AT-rich interaction domain 2; B cell CLL/lymphoma 11A; CREB binding protein; erb-b2 receptor tyrosine kinase 2 (ERBB2); exostosin glycosyltransferase 1; Fanconi anemia complementation group D2; mutS homolog 6 (MSH6), neurofibromin 1 (NF1); notch 1 (NOTCH1), nuclear mitotic apparatus protein 1; phosphodiesterase 4D interacting protein; protein phosphatase 2 scaffold subunit Aalpha (PPP2R $1 A$ ); ring finger protein 213; spectrin repeat containing nuclear envelope protein 1; CUB and Sushi multiple domains 3; latrophilin 3; LDL receptor related protein $1 \mathrm{~B}$; speckle type $\mathrm{BTB} / \mathrm{POZ}$ protein $(S P O P)$; speckle type BTB/POZ protein (KMT2D) and TP53 (21,24-27). The genetic mutations related to chromatin remodeling, DNA repair signaling, PI3K-AKT-mTOR, Notch signaling and CTNNB1 pathway may be involved in CCC biology (27). The frequently mutated genes were PIK3CA (60\%), ARIDIA (50\%) and PTEN (10\%) in CCC (27-31). Somatic mutations of these genes are common genetic changes. PIK3CA-Akt-mTOR pathway is commonly altered in CCC. Genes involved in chromatin remodeling, ARIDIA, PPP2R1A, SPOP and KMT2D, were mutated across CCC tumors (26). In ARIDIA mutant tumour cells, inhibition of ATR triggers genomic instability and cell death (32). Furthermore, tumor suppressor PTEN is mutated in a large number of cancers (33). Somatic PTEN mutations, PTEN c.678delC, PTEN c.968insA and PTEN p.R233X, were detected in CCC (16). PTEN loss associated with HR deficiency increased chemosensitivity and therapeutic ratio (34). siRNA screening strategies also identified a synthetic lethal genetic interaction between PTEN $(35,36)$ and $A T M$ as well as PTEN and nemo-like kinase (NLK) (33). Thus, PTEN may play a role in cisplatin and PARP inhibitor sensitivity in CCC.

Secondly, we focused on somatic mutations in genes in which drugs are applied and which are known to be involved in the repair of DNA and are functionally activated in CCC. These included BRCA1/2, ATR, ATM, BRCA1-associated RING domain 1 (BARD1), MRE11 homolog, double-strand break repair nuclease (MRE11), MMR genes, partner and localizer of $B R C A 2, R A D 51$, MAP kinse-ERK kinase mitogen-activated protein kinase kinase $1, K R A S, T P 53$, cyclin dependent kinase inhibitor 2A (CDKN2A), ERBB2 and NF1. The literature search provides examples of mutated genes: BRCA1 (BRCA1 1135insA), BRCA2 (BRCA2 p.S368X), ATM (ATM c.5441delT), CHEK2 (CHEK2 p.S428F and CHEK2 del exon 1-7) and MRE11 (MRE11A c.1196insTT) (16).

We also summarized key characteristics of these genes. Loss-of-function mutations of the BRCA1/2 genes occurred more frequently in HGSC compared to CCC (73 vs. $54 \%$, 89 vs. $80 \%$ ) (5), while somatic BRCA mutations were detected in CCC (16). ATR and ATM are cell cycle checkpoint kinases. Cell cycle checkpoint signaling pathways are required for DDR and then genomic stability. Inhibitors of the DDR pathways such as ATR, ATM, CHEK1 and CHEK2 are currently undergoing preclinical and early-phase clinical trials as single agents and in combinatorial regimens, including PARP inhibitors $(10,37,38)$. ATR inhibitors are currently assessed in clinical trials and show promising results (37). ATM is a synthetic lethal partner of PARP, TP53, or topoisomerase DNA I (39). BARDI is overexpressed in CCC (40). The BRCA1/ $B A R D 1$ complex is an HR DNA repair component. Partner and localizer of $B R C A 2$ (PALB2) play a role in DNA repair as a partner of $B R C A 1 / 2$. RAD51 family members functions in the early stage of HR DNA repair. Abnormal MMR expression was identified in $6 \%$ of CCC (33). Defective DNA MMR generates MRE11 mutations and sensitizes cancer cells to PARP1 inhibition, showing the synthetic lethality between MRE11 and PARP1 (41). MSH6 is a synthetic lethality partner of: dihydrofolate reductase; DNA polymerase $\beta$, catalytic subunit; DNA polymerase $\gamma$, catalytic subunit; or PTEN-induced putative kinase 1. mTOR pathway genes are often mutated in CCC (42). Thus, mTOR inhibitor may be one of the most promising approaches in CCC. Activating mutations in KRAS are identified in CCC. KRAS is a synthetic lethality partner of XIAP or RAD51 (43). TP53 is a synthetic lethality partner of ATM, ATR, CHEK1, ID1, or mTOR (44). LOH is detected at the $\mathrm{CDKN} 2 \mathrm{~A} / 2 \mathrm{~B}$ loci in $\mathrm{CCC}$ (45). $C D K N 2 A$ is a synthetic lethality partner of $R B 1$. $E R B B 2$ expression was upregulated in CCC (26). A synthetic lethality can be achieved with combined EGFR and PARP inhibition (46). NF1 and PARP are also synthetic lethality pairs (44). Taken together, a subset of CCC cells may be sensitive to PARP inhibition, which can be predicted by defects in HR DNA repair of DSBs (14).

\section{Upregulated genes enhancing synthetic lethality of PARP inhibitors in CCC (Table IB)}

Differentially expressed genes in human CCC tissues were identified using high-throughput tissue microarray technology 
Table I. Candidate genes enhancing synthetic lethality of PARP inhibitors in CCC.

A, Candidate mutated genes for enhancing the therapeutic ratio achieved by PARP inhibitors in CCC

\begin{tabular}{|c|c|c|c|c|c|}
\hline $\begin{array}{l}\text { Official } \\
\text { symbol }\end{array}$ & $\begin{array}{l}\text { Official } \\
\text { full name }\end{array}$ & Function & $\begin{array}{c}\text { Candidate } \\
\text { synthetic lethality } \\
\text { gene partners }\end{array}$ & $\begin{array}{l}\text { Somatic mutations } \\
\text { in } \mathrm{CCC}\end{array}$ & Refs. \\
\hline ARID1A & $\begin{array}{l}\text { AT-rich interaction } \\
\text { domain } 1 \mathrm{~A}\end{array}$ & $\begin{array}{l}\text { Chromatin } \\
\text { remodeling }\end{array}$ & ATR & & $\begin{array}{r}26,30, \\
31,32\end{array}$ \\
\hline ATM $^{\mathrm{a}}$ & $\begin{array}{l}\text { Ataxia telangiectasia } \\
\text { mutated serine/threonine } \\
\text { kinase }\end{array}$ & $\begin{array}{l}\text { DNA repair } \\
\text { checkpoint }\end{array}$ & PARP, TOP1, ATR & $\begin{array}{l}\text { Somatic HR mutation } \\
\text { in CCC, ATM } \\
\text { c. } 5441 \text { delT }\end{array}$ & $\begin{array}{r}16,37 \\
39\end{array}$ \\
\hline $\mathrm{ATR}^{\mathrm{a}}$ & $\begin{array}{l}\text { TM and } \\
\text { Rad3-related }\end{array}$ & $\begin{array}{l}\text { DNA repair } \\
\text { checkpoint }\end{array}$ & PARP & & $\begin{array}{r}10,29 \\
37,38\end{array}$ \\
\hline $\mathrm{BARD} 1^{\mathrm{a}}$ & $\begin{array}{l}\text { BRCA1-associated } \\
\text { RING domain } 1\end{array}$ & HR & PARP & $\begin{array}{l}\text { Expression of spliced } \\
\text { isoforms of BARD1 } \\
\text { was typical for clear } \\
\text { cell carcinoma (51) }\end{array}$ & 39,40 \\
\hline $\mathrm{BRCA} 1 / 2^{\mathrm{a}}$ & $\begin{array}{l}\text { BRCA } 1, \text { DNA } \\
\text { repair associated }\end{array}$ & HR & PARP & $\begin{array}{l}\text { Somatic HR mutation in } \\
\text { CCC, BRCA1 } 1135 \text { ins A, } \\
\text { BRCA2 p.S368X }\end{array}$ & 5,16 \\
\hline CDKN2A & $\begin{array}{l}\text { Cyclin dependent } \\
\text { kinase inhibitor } 2 \mathrm{~A}\end{array}$ & $\begin{array}{l}\text { Cell cycle } \\
\text { regulator }\end{array}$ & $\mathrm{RB} 1$ & & 45 \\
\hline $\mathrm{CHEK}^{\mathrm{a}}$ & $\begin{array}{l}\text { Checkpoint } \\
\text { kinase } 1\end{array}$ & $\begin{array}{l}\text { DNA repair } \\
\text { checkpoint }\end{array}$ & $\begin{array}{l}\text { ATR, MYC, } \\
\text { TP53, Wee1, p21 }\end{array}$ & $\begin{array}{l}\text { CHK1 is a homologous } \\
\text { recombination gene }\end{array}$ & 10,29 \\
\hline CHEK2 & $\begin{array}{l}\text { Checkpoint } \\
\text { kinase } 2\end{array}$ & $\begin{array}{l}\text { DNA repair } \\
\text { checkpoint }\end{array}$ & & $\begin{array}{l}\text { CHEK2 p.S428F and } \\
\text { CHEK2 del exon } 1-7\end{array}$ & 9,16 \\
\hline CREBBP & CREB binding protein & & p300 & & 58 \\
\hline ERBB2 & $\begin{array}{l}\text { erb-b2 receptor tyrosine } \\
\text { kinase } 2, \text { HER } 2\end{array}$ & Oncogene & PARP & & 26,46 \\
\hline FANCD2 & $\begin{array}{l}\text { Fanconi anemia } \\
\text { complementation group D2 }\end{array}$ & DNA repair & PARP, POLQ & & 67 \\
\hline KRAS & $\begin{array}{l}\text { KRAS proto-oncogene, } \\
\text { GTPase }\end{array}$ & Oncogene & XIAP, RAD51 & & 43 \\
\hline LZTS1 & $\begin{array}{l}\text { Leucine zipper } \\
\text { tumor suppressor } 1\end{array}$ & $\begin{array}{l}\text { Tumor } \\
\text { suppressor }\end{array}$ & $\mathrm{CDKN} 2 \mathrm{~A} / 2 \mathrm{~B}$ & & 45 \\
\hline MLH1 & mutL homolog 1 & $\begin{array}{l}\text { DNA mismatch } \\
\text { repair }\end{array}$ & ATR & & $\begin{array}{r}27,33 \\
39\end{array}$ \\
\hline MRE11A ${ }^{a}$ & $\begin{array}{l}\text { MRE11 homolog, } \\
\text { double strand break } \\
\text { repair nuclease }\end{array}$ & DNA repair & PARP & $\begin{array}{l}\text { Somatic HR mutation } \\
\text { in CCC, MRE11A } \\
\text { c.1196insTT }\end{array}$ & 41 \\
\hline MSH6 & $\begin{array}{l}\text { mutS } \\
\text { homolog } 6\end{array}$ & $\begin{array}{l}\text { DNA } \\
\text { mismatch repair }\end{array}$ & $\begin{array}{l}\text { DHFR, POLB, } \\
\text { POLG, PINK1 }\end{array}$ & & \\
\hline MTOR & $\begin{array}{l}\text { Mechanistic target of } \\
\text { rapamycin kinase }\end{array}$ & $\begin{array}{l}\text { Cell cycle } \\
\text { regulator }\end{array}$ & TP53 & & 42,44 \\
\hline NF1 & Neurofibromin 1 & Oncogene & PARP & & 44 \\
\hline NOTCH1 & Notch 1 & $\begin{array}{l}\text { Cell } \\
\text { processes }\end{array}$ & ERBB2, EGFR & & 68 \\
\hline PIK3CA & $\begin{array}{l}\text { Phosphatidylinositol-4,5 } \\
\text { bisphosphate3-kinase } \\
\text { catalytic subunit alpha }\end{array}$ & Oncogene & TRRAP, Hh & & 27,29 \\
\hline PPP2R1A & $\begin{array}{l}\text { Protein phosphatase } 2 \\
\text { scaffold subunit } \\
\text { Aalpha }\end{array}$ & Cell growth & PLK & $\begin{array}{l}7 \% \text { of } \mathrm{CCC} \text { had } \\
\text { mutations } \\
\text { in PPP2R1A. }\end{array}$ & 30 \\
\hline PRKDC & $\begin{array}{l}\text { Protein kinase, } \\
\text { DNA-activated, } \\
\text { catalytic polypeptide }\end{array}$ & DNA repair & MYC, MSH3 & & 24 \\
\hline
\end{tabular}


Table I. Continued.

A, Candidate mutated genes for enhancing the therapeutic ratio achieved by PARP inhibitors in CCC

\begin{tabular}{|c|c|c|c|c|c|}
\hline $\begin{array}{l}\text { Official } \\
\text { symbol }\end{array}$ & $\begin{array}{l}\text { Official } \\
\text { full name }\end{array}$ & Function & $\begin{array}{c}\text { Candidate } \\
\text { synthetic lethality } \\
\text { gene partners }\end{array}$ & $\begin{array}{l}\text { Somatic mutations } \\
\text { in } \mathrm{CCC}\end{array}$ & Refs. \\
\hline PTEN & $\begin{array}{l}\text { Polypeptide } \\
\text { phosphatase and } \\
\text { tensin homolog }\end{array}$ & $\begin{array}{l}\text { Tumor } \\
\text { suppressor }\end{array}$ & $\begin{array}{l}\text { PARP, } \\
\text { ATM, NLK }\end{array}$ & $\begin{array}{l}10 \% \text { of CCC had mutations } \\
\text { in PTEN. Somatic HR mutation } \\
\text { in CCC, PTEN c. } 678 \text { delC, } \\
\text { PTEN c. } 968 \text { insA, PTEN p.R } 233 X\end{array}$ & $\begin{array}{r}16,28 \\
33\end{array}$ \\
\hline RAD51C & RAD51 paralog C & DNA repair & PARP & & 14,43 \\
\hline PALB2 & $\begin{array}{l}\text { Partner and localizer } \\
\text { of BRCA2 }\end{array}$ & $\begin{array}{l}\text { BRCA2 } \\
\text { complex }\end{array}$ & PARP & & 69 \\
\hline TP53 & $\begin{array}{l}\text { Tumor protein } \\
\text { p53 }\end{array}$ & $\begin{array}{l}\text { Cell cycle } \\
\text { regulator }\end{array}$ & $\begin{array}{l}\text { ID1, CHK1, ATM, } \\
\text { ATR, mTOR }\end{array}$ & & $3,39,44$ \\
\hline XRCC5 & $\begin{array}{l}\text { X-ray repair cross } \\
\text { complementing } 5\end{array}$ & $\begin{array}{l}\text { DNA } \\
\text { repair }\end{array}$ & $\mathrm{Ku}$ & & 50 \\
\hline
\end{tabular}

B, Upregulated genes enhancing synthetic lethality of PARP inhibitors in CCC

\begin{tabular}{|c|c|c|c|c|}
\hline $\begin{array}{l}\text { Official } \\
\text { symbol }\end{array}$ & $\begin{array}{l}\text { Official } \\
\text { full name }\end{array}$ & Function & $\begin{array}{l}\text { Candidate synthetic } \\
\text { lethality gene partners }\end{array}$ & Refs. \\
\hline AURKA & Aurora kinase A & Cell cycle regulator & MYC & 5,51 \\
\hline $\mathrm{CCNE}^{\mathrm{a}}$ & Cyclin E1 & Cell cycle regulator & PARP & 47,54 \\
\hline $\mathrm{CKS}_{1} \mathrm{~B}^{\mathrm{a}}$ & $\begin{array}{l}\text { CDC28 protein kinase } \\
\text { regulatory subunit } 1 \mathrm{~B}\end{array}$ & $\begin{array}{l}\text { Cell cycle } \\
\text { regulator }\end{array}$ & PLK1 & 48 \\
\hline ERBB2 & $\begin{array}{l}\text { erb-b2 receptor } \\
\text { tyrosine kinase } 2 \text { (HER2) }\end{array}$ & Oncogene & NOTCH1 PARP & 26,46 \\
\hline HNF1B & $\begin{array}{l}\text { Hepatocyte nuclear } \\
\text { factor- } 1 \beta\end{array}$ & $\begin{array}{l}\text { Transcription } \\
\text { factor }\end{array}$ & CHEK1 & 49 \\
\hline PTEN $^{\mathrm{a}}$ & $\begin{array}{l}\text { Phosphatase and } \\
\text { tensin homolog }\end{array}$ & $\begin{array}{l}\text { Tumor } \\
\text { suppressor }\end{array}$ & $\begin{array}{l}\text { PARP, ATM, NLK, } \\
\text { (nemo like kinase) }\end{array}$ & $\begin{array}{r}33,35 \\
36\end{array}$ \\
\hline XRCC5 & $\begin{array}{l}\text { X-ray repair cross } \\
\text { complementing } 5\end{array}$ & DNA repair & $\mathrm{Ku}$ & 50 \\
\hline
\end{tabular}

C, Synthetic lethal gene partners based on chemoresistance-related genes in CCC

\begin{tabular}{|c|c|c|c|c|}
\hline $\begin{array}{l}\text { Official } \\
\text { symbol }\end{array}$ & $\begin{array}{l}\text { Official } \\
\text { full name }\end{array}$ & Function & $\begin{array}{l}\text { Candidate synthetic } \\
\text { lethality gene partners }\end{array}$ & Refs. \\
\hline $\mathrm{CHEK}^{\mathrm{a}}{ }^{\mathrm{a}}$ & $\begin{array}{l}\text { Checkpoint } \\
\text { kinase } 1\end{array}$ & $\begin{array}{l}\text { DNA repair } \\
\text { checkpoint }\end{array}$ & $\begin{array}{l}\text { ARR, MYC, TP53, } \\
\text { Wee1, p21 }\end{array}$ & $\begin{array}{r}29,60,61 \\
62,63\end{array}$ \\
\hline $\mathrm{DNMT}^{\mathrm{a}}$ & DNA methyltransferase 1 & Methyltransferase & PARP & 56,64 \\
\hline FGFR2 $^{\mathrm{a}}$ & Fibroblast growth factor receptor 2 & Oncogene & PTEN & 57 \\
\hline $\mathrm{ERBB}^{\mathrm{a}}$ & erb-b2 receptor tyrosine kinase 2 & Oncogene & PARP & 26 \\
\hline $\mathrm{MYC}^{\mathrm{a}}$ & $\begin{array}{l}\text { MYC proto-oncogene, } \\
\text { bHLH transcription factor }\end{array}$ & Oncogene & PTEN & 52,58 \\
\hline $\mathrm{NOTCH}^{\mathrm{a}}$ & Notch 1 & Cell processes & EGFR & $27,59,66$ \\
\hline
\end{tabular}

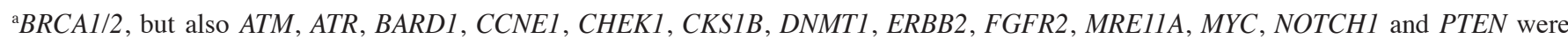
considered as candidate genes for synthetic lethality gene partners for PARP inhibitors.

and proteomic screening (18). Previous studies summarized the characteristics of potential genomic alterations that activate the CCC-specific gene ontology, canonical pathways and functional networks $(18,19)$. Among the genes overexpressed in CCC, we selected the genes showing growth inhibition by knockdown experiments. These analyses revealed a significant 
representation in the cell cycle regulation and DNA repair pathways (18-20). Overexpression of $H N F-1 \beta$ (>90\%), CHEK1, $\mathrm{X}$-ray repair cross complementing $(X R C C) 5$, cyclin $(C C N) \mathrm{E} 1$ and $\mathrm{CDC} 28$ protein kinase regulatory subunit $1 \mathrm{~B}(C K S 1 B)$ is a common genetic change in CCC $(28,29,47-49)$. A novel role for transcription factor $H N F-1 \beta$ in DDR was identified (49). CCC cells are dependent on the HNF-1 $\beta$-CHEK1 axis for cell survival (15). CCC cells exhibit the upregulation of HNF-1 $\beta$ expression and accumulate G1/S cell cycle arrest, which results in the constitutive expression of the activated CHEK1 in response to DNA damage (49). DNA repair protein XRCC5 functions as the repair of DNA DSBs by NHEJ (50). XRCC5 is the subunit of the $\mathrm{Ku}$ heterodimer protein, which is also known as ATP-dependent DNA helicase II. The cell-cycle regulators were frequently overexpressed (cyclin A and E) or downregulated cyclin-dependent kinase inhibitor $1 \mathrm{~B}$ $(C D K N 1 B)$, also known as $\mathrm{p} 27^{\mathrm{Kip} 1}$ in $\mathrm{CCC}$. Various oncogenes enhance the replication stress and increase the genomic instability of cancer cells (51-53). Overexpression of the oncogene CCNE1 has been observed in tumors, which also results in chromosomal instability characterized by accumulation of chromosome copy number aberrations. CCNE1 copy-number gain and overexpression have an impact following unfavorable outcome in CCC (47). Amplification of CCNE1 and mutation of $B R C A 1 / 2$ genes appear to be mutually exclusive, despite the high individual frequencies of such mutations in cancer (54). This suggests that CCNE1 induces synthetic lethality in BRCA1/2-mutated cells (54). CKS1B is a modulator of the cyclin-dependent kinase; cyclin-dependent serine/threonineprotein kinase $C D C 28$. A high throughput screening revealed that $C K S 1 B$ is a synthetic lethality partner of PLK1 (48). Although a variety of genes in CCC are passenger events, these genes may function as synthetic lethal pairs under the replication stress condition.

\section{Synthetic lethal gene partners based on chemoresi- stance-related genes in CCC (Table IC)}

The persistent existence of cancer stem cells plays a role in therapeutic drug resistance and cancer recurrence, which are the common cause for serious morbidity in cancer patients. Research studies have identified putative target genes associated with stem cell chemoresistance (55). Multiple oncogenes may function as attractive candidates that are involved in malignant behavior and acquisition of a chemoresistant phenotype. A number of user-friendly databases and tools in scientific workflows have been integrated to facilitate data analysis. The comprehensive information in the QIAGEN database (http:// www.sabiosciences.com/rt_pcr_product/HTML/PAHS-176Z. html) has been compiled from research publications. Genetic data on stem cell markers (n, 89) are publically available from this database. We selected 14 genes as the CCC-specific genes from this database using the PubMed literature search. Six genes were identified: $E R B B 2$; fibroblast growth factor receptor 2(FGFR2); MYC proto-oncogene, bHLH transcription factor $(M Y C)$; NOTCHI; CHEK1; and DNA methyltransferase 1 (DNMT1). These were predicted as synthetic lethality gene partners for PARP inhibitors $(26,27,56-58)$. Overexpression of oncogenes ERBB2, FGFR2 and MYC in CCC cells accelerates the DNA replication stress, accumulates DNA DSBs and associates with synthetic lethality to PARP1 inhibitors (46-52). A contextual synthetic lethality exists between the combined inhibition of ERBB2 and PARP (46). Simultaneous inhibition of ERBB2 and NOTCH1 also uncovers a synthetic lethal relationship (59). DNA damage or the presence of unreplicated DNA induces cell cycle arrest in G2/M phase in a manner regulated by $C H E K 1$ in CCC cells overexpressing HNF-1 $\beta$ (60). CHEK1 is reportedly a synthetic lethality partner of ATR, MYC, TP53, WEE1 G2 checkpoint kinase (WEE1), or cyclin-dependent kinase inhibitor 1A (CDKN1A), also known as p21 ${ }^{\mathrm{CIP} 1}(29,61-63)$. DNMT1 maintains methylation patterns following DNA replication. Combining DNMT1 inhibition and PARP inhibitors cause synthetic lethality (64). PARP inhibition prevents XRCC1 interaction with several DNA repair proteins, including DNMT1 and thereby insufficient organization of base excision repair (64). We can provide chemoresistance or stem cell-related genes for synthetic lethality pairs of PARP inhibitors in CCC. This study has the potential to strengthen the fact that activating oncogene mutations or amplifications (for example, ERBB2, FGFR2, MYC, KRAS and PIK3CA) suggest a synthetic lethal-based therapeutic strategy (57).

\section{Discussion}

This article reviewed the conceptual biology leading to the prediction of novel synthetic lethality pairs and discussed the rationale for antitumor strategies in CCC (37). We conducted a literature review for putative PARP sensitivity genes associated with CCC pathophysiology. A variety of target genes were identified from DNA repair pathways, chromatin remodeling complex, PI3K-AKT-mTOR pathways, Notch signaling pathways, cell cycle checkpoint signaling pathways, BRCA-associated pathways and Fanconi's anemia susceptibility genes. ATM, ATR, BARD1, BRCA1/2, CCNE1, CHEK1, CKS1B, DNMT1, ERBB2, FGFR2, MRE11A, MYC, NOTCH1 and $P T E N$ were considered as candidate genes for synthetic lethality gene partners for PARP inhibitors.

Firstly, the assembly of HR proteins at sites of DNA damage led to the activation of signal transducers, including ATM, ATR, and DNA-dependent protein kinase (DNA-PK), which activate downstream effectors, CHEK1/2, and in turn DNA repair pathways. During DDR, the checkpoint signal transducers/effectors such as ATM/CHEK2 and ATR/CHEK1 regulate $\mathrm{G} 1 / \mathrm{S}$ and $\mathrm{G} 2 / \mathrm{M}$ checkpoints, respectively, and induce cell cycle arrest (9). ATM mutations in parallel to the ATR-CHEK1 axis induce high replication stress (16). The HR deficiency caused by ATM mutations sensitizes tumor cells to potent inhibitors of PARP-mediated signaling (39). Inhibitors of ATM may be a promising strategy for cancer therapy (38). $A T R$ and CHEK1 are synthetic lethal pairs between two proteins in the same pathway and maintain cancer cell survival under replication stress $(10,29)$. CCC have been assumed to demonstrate an increased reliance on the HNF-1 $\beta$ CHEK1 axis for cell survival (49). Significant genes involved in synthetic lethality with $C H E K 1$ are reported to be ATR, $M Y C, T P 53, W E E 1$ and $C D K N 1 A(29,61-63)$. ATR inhibition is currently assessed in early-phase clinical trials as single agents and in combination strategies, including PARP inhibitors (37). Inhibitors of the major components of the DDR such as ATM, ATR, DNA-PK, CHEK1 and CHEK2 would be used to confer 
chemosensitivity upon CCC. Therefore, PARP inhibitors may induce synthetic lethality in CCC tumors with mutated genes that regulate HR repair and associated events such as cell cycle checkpoints. Although a variety of loss-of-function and gain-of-function genes in CCC are passenger events, the DNA repair genes, such as $A T M, A T R$, and $C H E K 1$, may function as synthetic lethal pairs under the replication stress condition.

Secondly, activating oncogene mutations or amplifications are putative synthetic lethality gene partners for PARP inhibitors in CCC. Overexpression of oncogenes, $E R B B 2$, $M Y C$ and $C C N E 1$, in CCC activates MAPK and PI3K signaling pathways (26). It has been shown that ERBB2 and $M Y C$ represses cellular DSB repair potentials due to an increase in replication stress (46). A contextual synthetic lethality can be achieved with combined oncogenes and PARP inhibition. Therefore, PARP inhibitors demonstrate synthetic lethality in CCC tumors with activating oncogene mutations and oncogene amplifications (46). Furthermore, synthetic lethality partners for $E R B B 2$ mutant and overexpression using functional and profiling screenings are considered to be SWI/SNF subunits, NF- $\kappa$ B pathway, STAT3 pathways, MAP kinases, Wnt signaling, Src family kinases, cyclin-dependent kinases and Notch signaling (65). CCNE1 amplification and $B R C A 1 / 2$ inactivation are mutually exclusive and known to promote genomic instability and tumor progression (54). Thus, PARP inhibitors may sensitize CCC cells with oncogene mutant and overexpression to cisplatin in a synthetic lethal manner.

Thirdly, Notch signaling, chromatin remodeling, PI3KAKT-mTOR and CTNNB1 pathways may promote malignant transformation of CCC (27). Notch signaling controls cell processes, including cancer cell and cancer stem cell fate determination. NOTCH2 expression is specifically downregulated in CCC (66). Notch signaling and ERBB2 appear to be mutually exclusive, demonstrating that Notch signaling is also a potential synthetic lethal partner of ERBB2 (67).

Finally, tumor suppressors ARIDIA and PTEN are mutated in a large number of cancers. The mutations are also commonly observed in CCC (33). PTEN is a synthetic lethality partner for PARP, ATM, or NLK, while ARIDIA and ATR are synthetic lethal pairs $(33,35,36)$. Applications of PARP inhibition are now being expanded to tumor suppressor genes ARIDIA and PTEN.

In conclusion, our study aimed to examine the possible synthetic lethality gene partners for PARP inhibitors among genes aberrantly expressed in CCC. Increasing efforts have been focused on the identification of synthetic lethality gene partners for PARP inhibitors in a variety of cancers (68). Most PARP inhibitors have been investigated in HGSC, but not CCC, showing promising efficacy in patients with BRCA mutations and HR deficiency. In this review, virtual screening genes were selected and some genes were further tested via in vitro and in vivo assays. Considering the biological background underlying PARP inhibition, we hypothesized that PARP inhibitors would also be a novel synthetic lethal therapeutic approach for $\mathrm{CCC}$ tumors harboring activating mutations and overexpressed genes. The majority of CCC tumors appear to have indicators of DNA repair dysfunction similar to those in BRCA-mutation carriers in HGSC, suggesting the possible utility of PARP inhibitors in a subset of CCC. An improved understanding of the synthetic lethality on treatment strategies may facilitate a transition from chemotherapy alone to combination with synthetic lethality treatment strategies in CCC. In the future the use of PARP inhibitors may be extended beyond tumors with BRCA1/2 mutations.

\section{Acknowledgements}

The present study was supported by Grant-in-Aid for Scientific Research from the Ministry of Education, Science and Culture of Japan to the Department of Obstetrics and Gynecology, Nara Medical University (awarded to H.K.).

\section{References}

1. Stewart SL: Ovarian cancer incidence: Current and comprehensive statistics. In: Ovarian cancer-clinical and therapeutic perspectives. Farghaly S (ed). In Tech, Rijeka, Croatia, pp 1-15, 2012.

2. Kurman RJ and Shih IeM: Pathogenesis of ovarian cancer: Lessons from morphology and molecular biology and their clinical implications. Int J Gynecol Pathol 27: 151-160, 2008.

3. Mackenzie R, Talhouk A, Eshragh S, Lau S, Cheung D, Chow C, Le N, Cook LS, Wilkinson N, McDermott J, et al: Morphologic and molecular characteristics of mixed epithelial ovarian cancers. Am J Surg Pathol 39: 1548-1557, 2015.

4. Thompson N, Adams DJ and Ranzani M: Synthetic lethality: Emerging targets and opportunities in melanoma. Pigment Cell Melanoma Res 30: 183-193, 2017.

5. Li M, Li H, Liu F, Bi R, Tu X, Chen L, Ye S and Cheng X: Characterization of ovarian clear cell carcinoma using target drug-based molecular biomarkers: Implications for personalized cancer therapy. J Ovarian Res 10: 9, 2017.

6. Ledermann J, Harter P, Gourley C, Friedlander M, Vergote I, Rustin G, Scott CL, Meier W, Shapira-Frommer R, Safra T, et al: Olaparib maintenance therapy in patients with platinum-sensitive relapsed serous ovarian cancer: A preplanned retrospective analysis of outcomes by BRCA status in a randomised phase 2 trial. Lancet Oncol 15: 852-861, 2014.

7. Mackay HJ, Brady MF, Oza AM, Reuss A, Pujade-Lauraine E, Swart AM, Siddiqui N, Colombo N, Bookman MA, Pfisterer J, et al: Gynecologic cancer intergroup: Prognostic relevance of uncommon ovarian histology in women with stage III/IV epithelial ovarian cancer. Int J Gynecol Cancer 20: 945-952, 2010.

8. Sugiyama T, Kamura T, Kigawa J, Terakawa N, Kikuchi Y, Kita T, Suzuki M, Sato I and Taguchi K: Clinical characteristics of clear cell carcinoma of the ovary: A distinct histologic type with poor prognosis and resistance to platinum-based chemotherapy. Cancer 88: 2584-2589, 2000.

9. Leary A, Auguste A and Mesnage S: DNA damage response as a therapeutic target in gynecological cancers. Curr Opin Oncol 28: 404-411, 2016.

10. Murai J: Targeting DNA repair and replication stress in the treatment of ovarian cancer. Int J Clin Oncol 22: 619-628, 2017.

11. O'Sullivan Coyne G, Chen AP, Meehan R and Doroshow JH: PARP inhibitors in reproductive system cancers: Current use and developments. Drugs 77: 113-130, 2017.

12. Ang YLE and Tan DSP: Development of PARP inhibitors in gynecological malignancies. Curr Probl Cancer 41: 273-286, 2017.

13. Rajawat J, Shukla N and Mishra DP: Therapeutic targeting of Poly(ADP-Ribose) Polymerase-1 (PARP1) in cancer: Current developments, therapeutic strategies, and future opportunities. Med Res Rev: May 16, 2017 (Epub ahead of print).

14. Wilkerson PM, Dedes KJ, Samartzis EP, Dedes I, Lambros MB, Natrajan R, Gauthier A, Piscuoglio S, Töpfer C, Vukovic V, et al: Preclinical evaluation of the PARP inhibitor BMN-673 for the treatment of ovarian clear cell cancer. Oncotarget 8: 6057-6066, 2017

15. Steffensen KD, Adimi P and Jakobsen A: Veliparib monotherapy to patients with BRCA germ line mutation and platinum-resistant or partially platinum-sensitive relapse of epithelial ovarian cancer: A Phase I/II study. Int J Gynecol Cancer: Aug 1, 2017 (Epub ahead of print). 
16. Pennington KP, Walsh T, Harrell MI, Lee MK, Pennil CC, Rendi MH, Thornton A, Norquist BM, Casadei S, Nord AS, et al: Germline and somatic mutations in homologous recombination genes predict platinum response and survival in ovarian, fallopian tube and peritoneal carcinomas. Clin Cancer Res 20: 764-775, 2014.

17. Dougherty BA, Lai Z, Hodgson DR, Orr MCM, Hawryluk M, Sun J, Yelensky R, Spencer SK, Robertson JD, Ho TW, et al: Biological and clinical evidence for somatic mutations in BRCA1 and BRCA2 as predictive markers for olaparib response in high-grade serous ovarian cancers in the maintenance setting. Oncotarget 8: 43653-43661, 2017.

18. Kobayashi H, Sugimoto H, Onishi S and Nakano K: Novel biomarker candidates for the diagnosis of ovarian clear cell carcinoma. Oncol Lett 10: 612-618, 2015.

19. Kajihara H, Yamada Y, Kanayama S, Furukawa N, Noguchi T, Haruta S, Yoshida S, Sado T, Oi H and Kobayashi H: Clear cell carcinoma of the ovary: Potential pathogenic mechanisms (Review). Oncol Rep 23: 1193-1203, 2010.

20. Kobayashi H, Kajiwara H, Kanayama S, Yamada Y, Furukawa N Noguchi T, Haruta S, Yoshida S, Sakata M, Sado T, et al: Molecular pathogenesis of endometriosis-associated clear cell carcinoma of the ovary (review). Oncol Rep 22: 233-240, 2009.

21. Maru Y, Tanaka N, Ohira M, Itami M, Hippo Y and Nagase H: Identification of novel mutations in Japanese ovarian clear cell carcinoma patients using optimized targeted NGS for clinical diagnosis. Gynecol Oncol 144: 377-383, 2017.

22. Bajrami I, Frankum JR, Konde A, Miller RE, Rehman FL, Brough R, Campbell J, Sims D, Rafiq R, Hooper S, et al: Genome-wide profiling of genetic synthetic lethality identifies CDK12 as a novel determinant of PARP1/2 inhibitor sensitivity. Cancer Res 74: 287-297, 2014.

23. Wittig-Blaich S, Wittig R, Schmidt S, Lyer S, BewerungeHudler M, Gronert-Sum S, Strobel-Freidekind O, Müller C, List M, Jaskot A, et al: Systematic screening of isogenic cancer cells identifies DUSP6 as context-specific synthetic lethal target in melanoma. Oncotarget 8: 23760-23774, 2017.

24. Spreafico A, Oza AM, Clarke BA, Mackay HJ, Shaw P, Butler M, Dhani NC, Lheureux S, Wilson MK, Welch S, et al: Genotype-matched treatment for patients with advanced type I epithelial ovarian cancer (EOC). Gynecol Oncol 144 250-255, 2017.

25. Huang HN, Lin MC, Huang WC, Chiang YC and Kuo KT: Loss of ARID1A expression and its relationship with PI3K-Akt pathway alterations and ZNF217 amplification in ovarian clear cell carcinoma. Mod Pathol 27: 983-990, 2014

26. Arildsen NS, Jönsson JM, Bartuma K, Ebbesson A, Westbom-Fremer S, Måsbäck A, Malander S, Nilbert M and Hedenfalk IA: Involvement of chromatin remodeling genes and the Rho GTPases RhoB and CDC42 in ovarian clear cell carcinoma. Front Oncol 7: 109, 2017.

27. Er TK, Su YF, Wu CC, Chen CC, Wang J, Hsieh TH, Herreros-Villanueva M, Chen WT, Chen YT, Liu TC, et al: Targeted next-generation sequencing for molecular diagnosis of endometriosis-associated ovarian cancer. J Mol Med (Berl) 94 835-847, 2016

28. Worley MJ Jr, Liu S, Hua Y, Kwok JS, Samuel A, Hou L, Shoni M, Lu S, Sandberg EM, Keryan A, et al: Molecular changes in endometriosis-associated ovarian clear cell carcinoma. Eur J Cancer 51: 1831-1842, 2015.

29. Sanjiv K, Hagenkort A, Calderón-Montaño JM, Koolmeister T, Reaper PM, Mortusewicz O, Jacques SA, Kuiper RV, Schultz N, Scobie M, et al: Cancer-specific synthetic lethality between ATR and CHK1 kinase activities. Cell Reports 17: 3407-3416, 2016.

30. Maeda D, Mao TL, Fukayama M, Nakagawa S, Yano T, Taketani Y and Shih IeM: Clinicopathological significance of loss of ARID1A immunoreactivity in ovarian clear cell carcinoma. Int J Mol Sci 11: 5120-5128, 2010.

31. Wiegand KC, Shah SP, Al-Agha OM, Zhao Y, Tse K, Zeng T, Senz J, McConechy MK, Anglesio MS and Kalloger SE: ARID1A mutations in endometriosis-associated ovarian carcinomas. N Engl J Med 363: 1532-1543, 2010.

32. Williamson CT, Miller R, Pemberton HN, Jones SE, Campbell J, Konde A, Badham N, Rafiq R, Brough R, Gulati A, et al: ATR inhibitors as a synthetic lethal therapy for tumours deficient in ARID1A. Nat Commun 7: 13837, 2016.

33. Bennett JA, Morales-Oyarvide V, Campbell S, Longacre TA and Oliva E: Mismatch repair protein expression in clear cell carcinoma of the ovary: Incidence and morphologic associations in 109 cases. Am J Surg Pathol 40: 656-663, 2016.
34. McCormick A, Earp E, Leeson C, Dixon M, O'Donnell R, Kaufmann A and Edmondson RJ: Phosphatase and tensin homolog is a potential target for ovarian cancer sensitization to cytotoxic agents. Int J Gynecol Cancer 26: 632-639, 2016.

35. Mizuno T, Suzuki N, Makino H, Furui T, Morii E, Aoki H, Kunisada T, Yano M, Kuji S, Hirashima Y, et al: Cancer stem-like cells of ovarian clear cell carcinoma are enriched in the ALDH-high population associated with an accelerated scavenging system in reactive oxygen species. Gynecol Oncol 137: 299-305, 2015 .

36. Heinzelmann-Schwarz VA, Gardiner-Garden M, Henshall SM, Scurry J, Scolyer RA, Davies MJ, Heinzelmann M, Kalish LH, Bali A, Kench JG, et al: Overexpression of the cell adhesion molecules DDR1, Claudin 3, and Ep-CAM in metaplastic ovarian epithelium and ovarian cancer. Clin Cancer Res 10: 4427-4436, 2004.

37. Sundar R, Brown J, Ingles Russo A and Yap TA: Targeting ATR in cancer medicine. Curr Probl Cancer 41: 302-315, 2017.

38. Furgason JM and Bahassi el M: Targeting DNA repair mechanisms in cancer. Pharmacol Ther 137: 298-308, 2013.

39. Li Z, Pearlman AH and Hsieh P: DNA mismatch repair and the DNA damage response. DNA Repair (Amst) 38: 94-101, 2016.

40. Li L, Ryser S, Dizin E, Pils D, Krainer M, Jefford CE, Bertoni F, Zeillinger $\mathrm{R}$ and Irminger-Finger I: Oncogenic BARD1 isoforms expressed in gynecological cancers. Cancer Res 67: 11876-11885, 2007

41. Vilar E, Bartnik CM, Stenzel SL, Raskin L, Ahn J, Moreno V, Mukherjee B, Iniesta MD, Morgan MA, Rennert G, et al: MRE11 deficiency increases sensitivity to poly(ADP-ribose) polymerase inhibition in microsatellite unstable colorectal cancers. Cancer Res 71: 2632-2642, 2011.

42. Elvin JA, Chura J, Gay LM and Markman M: Comprehensive genomic profiling (CGP) of ovarian clear cell carcinomas (OCCC) identifies clinically relevant genomic alterations (CRGA) and targeted therapy options. Gynecol Oncol Rep 20: 62-66, 2017.

43. Kalimutho M, Bain AL, Mukherjee B, Nag P, Nanayakkara DM, Harten SK, Harris JL, Subramanian GN, Sinha D, Shirasawa S, et al: Enhanced dependency of KRAS-mutant colorectal cancer cells on RAD51-dependent homologous recombination repair identified from genetic interactions in Saccharomyces cerevisiae. Mol Oncol 11: 470-490, 2017.

44. Ye H, Zhang X, Chen Y, Liu Q and Wei J: Ranking novel cancer driving synthetic lethal gene pairs using TCGA data. Oncotarget 7: 55352-55367, 2016.

45. Kuo KT, Mao TL, Chen X, Feng Y, Nakayama K, Wang Y, Glas R, Ma MJ, Kurman RJ, Shih IeM, et al: DNA copy numbers profiles in affinity-purified ovarian clear cell carcinoma. Clin Cancer Res 16: 1997-2008, 2010.

46. Nowsheen S, Cooper T, Stanley JA and Yang ES: Synthetic lethal interactions between EGFR and PARP inhibition in human triple negative breast cancer cells. PLoS One 7: e46614, 2012.

47. Ayhan A, Kuhn E, Wu RC, Ogawa H, Bahadirli-Talbott A, Mao TL, Sugimura H, Shih IM and Wang TL: CCNE1 copy-number gain and overexpression identify ovarian clear cell carcinoma with a poor prognosis. Mod Pathol 30: 297-303, 2017.

48. Reid RJ, Du X, Sunjevaric I, Rayannavar V, Dittmar J, Bryant E, Maurer M and Rothstein R: A synthetic dosage lethal genetic interaction between CKS1B and PLK1 is conserved in yeast and human cancer cells. Genetics 204: 807-819, 2016.

49. Shigetomi H, Sudo T, Shimada K, Uekuri C, Tsuji Y, Kanayama S, Naruse K, Yamada Y, Konishi N and Kobayashi H: Inhibition of cell death and induction of G2 arrest accumulation in human ovarian clear cells by HNF-1 $\beta$ transcription factor: Chemosensitivity is regulated by checkpoint kinase CHK1. Int J Gynecol Cancer 24: 838-843, 2014.

50. Weterings E, Gallegos AC, Dominick LN, Cooke LS, Bartels TN, Vagner J, Matsunaga TO and Mahadevan D: A novel small molecule inhibitor of the DNA repair protein Ku70/80. DNA Repair (Amst) 43: 98-106, 2016.

51. Takahashi Y, Sheridan P, Niida A, Sawada G, Uchi R, Mizuno H, Kurashige J, Sugimachi K, Sasaki S, Shimada Y, et al: The AURKA/TPX2 axis drives colon tumorigenesis cooperatively with MYC. Ann Oncol 26: 935-942, 2015.

52. Maifrede S, Martin K, Podszywalow-Bartnicka P, Sullivan K, Langer SK, Nejadi R, Dasgupta Y, Hulse M, Gritsyuk D, Nieborowska-Skorska M, et al: IGH/MYC translocation associates with BRCA2 deficiency and synthetic lethality to PARP1 inhibitors. Mol Cancer Res. 15: 967-972, 2017. 
53. Etemadmoghadam D, Weir BA, Au-Yeung G, Alsop K, Mitchell G, George J, Davis S, D'Andrea AD, Simpson K, Hahn WC, et al: Australian ovarian cancer study group: Synthetic lethality between CCNE1 amplification and loss of BRCA1. Proc Natl Acad Sci USA 110: 19489-19494, 2013.

54. Zhan Q, Wang C and Ngai S: Ovarian cancer stem cells: A new target for cancer therapy. BioMed Res Int 2013: 916819, 2013

55. Chen CL, Yan X, Gao YN and Liao QP: Expression of DNA methyltransferase 1,3A and 3B mRNA in the epithelial ovarian carcinoma. Zhonghua Fu Chan Ke Za Zhi 40: 770-774, 2005. (In Chinese).

56. Itamochi H, Oumi N, Oishi T, Taniguchi F, Shoji T, Fujiwara H, Sugiyama T, Suzuki M, Kigawa J and Harada T: Fibroblast growth factor receptor 2 is associated with poor overall survival in clear cell carcinoma of the ovary and may be a novel therapeutic approach. Int J Gynecol Cancer 25: 570-576, 2015.

57. Chen CH, Shen J, Lee WJ and Chow SN: Overexpression of cyclin D1 and c-Myc gene products in human primary epithelial ovarian cancer. Int J Gynecol Cancer 15: 878-883, 2005.

58. Dong Y, Li A, Wang J, Weber JD and Michel LS: Synthetic lethality through combined notch-epidermal growth factor receptor pathway inhibition in basal-like breast cancer. Cancer Res 70: 5465-5474, 2010

59. Kobayashi H, Shigetomi $\mathrm{H}$ and Yoshimoto C: Checkpoint kinase 1 inhibitors as targeted molecular agents for clear cell carcinoma of the ovary. Oncol Lett 10: 571-576, 2015.

60. Gadhikar MA, Sciuto MR, Alves MV, Pickering CR, Osman AA, Neskey DM, Zhao M, Fitzgerald AL, Myers JN and Frederick MJ: Chk1/2 inhibition overcomes the cisplatin resistance of head and neck cancer cells secondary to the loss of functional p53. Mol Cancer Ther 12: 1860-1873, 2013.

61. Carrassa L, Chilà R, Lupi M, Ricci F, Celenza C, Mazzoletti M Broggini $\mathrm{M}$ and Damia G: Combined inhibition of Chk1 and Wee1: In vitro synergistic effect translates to tumor growth inhibition in vivo. Cell Cycle 11: 2507-2517, 2012.
62. Origanti S, Cai SR, Munir AZ, White LS and Piwnica-Worms H: Synthetic lethality of Chk1 inhibition combined with p53 and/or p21 loss during a DNA damage response in normal and tumor cells. Oncogene 32: 577-588, 2013.

63. Orta ML, Höglund A, Calderón-Montaño JM, Domínguez I, Burgos-Morón E, Visnes T, Pastor N, Ström C, López-lázaro M and Helleday T: The PARP inhibitor olaparib disrupts base excision repair of 5-aza-2"-deoxycytidine lesions. Nucleic Acids Res 42: 9108-9120, 2014.

64. Vyse S, Howitt A and Huang PH: Exploiting synthetic lethality and network biology to overcome EGFR inhibitor resistance in lung cancer. J Mol Biol 429: 1767-1786, 2017.

65. Galic V, Shawber CJ, Reeves C, Shah M, Murtomaki A, Wright J, Herzog T, Tong GX and Kitajewski J: NOTCH2 expression is decreased in epithelial ovarian cancer and is related to the tumor histological subtype. Pathol Discov 1: 4, 2013.

66. Wiegmans AP, Yap PY, Ward A, Lim YC and Khanna KK: Differences in expression of key DNA damage repair genes after epigenetic-induced BRCaness dictate synthetic lethality with PARP1 inhibition. Mol Cancer Ther 14: 2321-2331, 2015.

67. Gao Y, Rankin GO, Tu Y and Chen YC: Theaflavin-3, 3'-digallate decreases human ovarian carcinoma OVCAR-3 cell-induced angiogenesis via Akt and Notch-1 pathways, not via MAPK pathways. Int J Oncol 48: 281-292, 2016.

68. Metzger MJ, Stoddard BL and Monnat RJ Jr: PARP-mediated repair, homologous recombination, and back-up non-homologous end joining-like repair of single-strand nicks. DNA Repair (Amst) 12: 529-534, 2013 